\title{
Dampak Belajar Dari Rumah (BDR) dalam Perencanaan Karir Siswa
}

\author{
Fitri Aulia \\ Universitas Hamzanwadi Lombok Timur \\ Fitriaulia04@gmail.com \\ Mujidaturruhil Millah \\ Universitas Hamzanwadi Lombok Timur \\ Milac3338@gmail.com \\ Musifuddin \\ Universitas Hamzanwadi Lombok Timur \\ shief70@gmail.com
}

\begin{abstract}
This study aims to determine the impact of learning from home (BDR) in career planning for class XI MA NW Samawa students class XI MA NW Samawa and to find out the factores that influence the understanding of career planning during the BDR period. This research approach uses a qualitative approach with a case study method. The population in this study were students. .data collection techniques using observation techniques, interviews, and documentation. Based on the results of research on class XI students at the MA NW Samawa school, the results showed that the implementation of learning from home (BDR) had an impact on career planning for students in class XI MA NW Samawa. it means that students experience obstacles in planning intensive career planning. Students lack information related to career planning, lack of understanding of students to know themselves, students' unpreparedness in planning their careers. .it means that students have not been able to plan their future careers, students have not understood the steps in career planning which include: recognizing talents, paying attention to interests, paying attention to values, paying attention to personality, and understanding their potential. .This study has proven that the implementation of learning from home (BDR) has an impact on career planning for class XI students at MA NW Samawa.
\end{abstract}


Keywords: Study from home; career planning; MA NW Samawa.

\begin{abstract}
Abstrak
Penelitian ini bertujuan untuk mengetahui dampak belajar dari rumah (BDR) dalam perencanaan karir siswa kelas XI MA NW Samawa dan untuk mengetahui factor yang mempengaruhi pemahaman perencanaan karir di masa BDR tersebut. Pendekatan penelitian ini menggunakan pendekatan kualitatif dengan metode studi kasus. Populasi dalam penelitian ini adalah siswa kelas XI IPS MA NW Samawa. Teknik pengumpulan data menggunakan teknik observasi, wawancara, dan dokumentasi. Berdasarkan hasil penelitian pada siswa kelas XI di sekolah MA NW Samawa, hasil penelitian menunjukan bahwa pelaksanaan belajar dari rumah (BDR) berdampak dalam perencanaan karir siswa kelas XI MA NW Samawa. Artinya bahwa siswa mengalami hambatan-hambatan dalam merencanakan perencanaan karir secara intensif. Siswa kekurangan informasi terkait perencanaan karir, Kurangnya pemahaman siswa untuk mengenal diri, Ketidaksiapan siswa dalam perencanaan karirnya. Artinya bahwa siswa belum mampu dalam merencanakan karir masa depannya, siswa belum memahami langkah-langkah dalam perencanaan karir yang meliputi: mengenali bakat, memperhatikan minat, memperhatikan nilai-nilai, memeperhatikan kepribadian, dan memahami potensi yang dimiliki. Penelitian ini telah membuktikan bahwa pelaksanaan belajar dari rumah (BDR) berdampak dalam perencaan karir siswa kelas XI MA NW Samawa.
\end{abstract}

Kata kunci: Belajar dari rumah; perencanaan karir; MA NW Samawa

\title{
Pendahuluan
}

Kondisi pandemic Covid-19 telah mempengaruhi hampir seluruh aspek kehidupan manusia. Untuk memutus mata rantai penularan virus tersebut, banyak pembatasan yang dilakukan oleh pemerintah, termasuk pemerintah Indonesia. Dalam rangka mencegah meluasnya penularan Covid-19 pada warga sekolah khususnya dan masyarakat umumnya, kementrian pendidikan dan kebudayaan (Kemendikbud) menerbitkan beberapa surat edaran terkait Pencegahan dan Penanganan Covid-19. Pertama, Surat Edaran Nomor 2 Tahun 2020 tentang pencegahan dan penanganan Covid-19 di lingkungan Kemendikbud. Kedua, Surat Edaran Nomor 3 Tahun 2020 tentang Pencegahan Covid-19 pada Satuan Pendidikan. Ketiga, Surat Edaran Nomor 4 Tahun 2020 tentang Pelaksanaan Kebijakan Pendidikan dalam Masa Darurat Penyebaran 
Corona Virus Disease (Covid-19) yang antara lain memuat arahan tentang proses belajar dari rumah (BDR).

Pendidikan merupakan salah satu sektor yang terdampak wabah Covid19 di masa pandemi. Penyelenggaraan pendidikan di tengah-tengah pandemi akhirnya dilakukan melalui sistem belajar dari rumah (BDR) berbantuan perangkat komunikasi elektronik berbasis online. Hal ini ditempuh oleh pemerintah melalui menteri pendidikan dengan tujuan agar siswa tetap mendapatkan hak sebagai pelajar yaitu menerima layanan bimbingan dan pembelajaran selama berada di rumah (Puradina \& Winaya, 2020). Belajar dari rumah juga memiliki tujuan agar siswa terhidar dari dampak Covid-19.

Dampak Belajar dari rumah (BDR) yang dirasakan siswa memang cukup kompleks, ada positif dan negatif. Dampak negative dari aspek psikologis, gejalanya adalah (a) anak menjadi malas belajar mandiri di rumah karena merasa kesepian, hal ini dikarenakan lingkungan belajar berlangsung tidak seperti sekolah normal. ${ }^{1}$ Dimana anak-anak biasa belajar bersama dengan guru dan temannya. (b) anak mudah stress, emosi anak-anak seringkali berubah seiring dengan situasi dan kondisi lingkungan. ${ }^{2}$ Tingkat stress anak-anak dalam proses belajar dari rumah meningkat tajam dibanding belajar tatap muka. ${ }^{3}$ Sebagian anak juga ditemukan sikap acuh tak acuh, tidak peduli dan terkesan meremehkan terhadap tugas yang diberikan guru. Siswa juga tidak terlatih mandiri karena sering bergantung kepada orang tua dan keluarga dalam pemenuhan tugasnya. ${ }^{4}$

Melalui pembelajaran dari rumah, siswa jenuh dengan rutinitas yang sama yang harus mereka jalani setiap hari. Menurut ${ }^{5}$ Proses belajar mengajar yang didominasi guru dengan metode ceramah dan penugasan individual kurang tepat, karena pembelajaran menjadi tidak menarik dan membuat siswa merasa jenuh serta terbebani, suasana belajar menjadi tidak menyenangkan. Dalam kondisi dan situasi seperti itu, kemampuan siswa untuk menerima dan

${ }^{1}$ Usama Luthfi Alkindi, S Pd SD, and S D N Kalasan Baru, "Pembelajaran Jarak Jauh Penuh Motivasi," Pembelajaran Di Masa Pandemi, Inovasi Tiada Henti (Kumpulan Best Practices Inovasi Pembelajaran), 2021, 43.

2 Andi Suhandi and Issaura Sherly Pamela, "Dampak Musim Libur Covid-19 Belajar Dari Rumah Terhadap Psikologi Anak Sekolah Dasar," Jurnal Gentala Pendidikan Dasar 5, no. 2 (2020): 207-18.

${ }^{3}$ Tri Nathalia Palupi, “Tingkat Stres Ibu Dalam Mendampingi Siswa-Siswi Sekolah Dasar Selama Belajar Di Rumah Pada Masa Pandemi Covid-19," Jurnal Psikologi Pendidikan Dan Pengembangan SDM 10, no. 1 (2021): 36-48.

${ }^{4}$ Yulia Khurriyati, Fajar Setiawan, and Lilik Binti Mirnawati, "Dampak Pembelajaran Daring Terhadap Hasil Belajar Siswa Mi Muhammadiyah 5 Surabaya," Jurnal Ilmiah Pendidikan Dasar 8, no. 1 (2021): 91-104.

${ }^{5}$ Hamzah Upu Jusmawati and Muhammad Darwis, "Efektivitas Penerapan Model Berbasis Masalah Setting Kooperatif Dengan Pendekatan Saintifik Dalam Pembelajaran Matematika Di Kelas X SMA Negeri 11 Makassar," Daya Matematis: Jurnal Inovasi Pendidikan Matematika 3, no. 1 (2015): 30-40. 
memahami materi pelajaran tidak maksimal. Hal tersebut tercermin dari nilai tes yang belum memuaskan.

Fenomena lain yang ditemukan di SMA di Kabupaten Lombok Tengah tentang kebijakan pembelajaran jarak jauh dalam jaringan (daring) dan pembelajaran jarak jauh luar jaringan (luring) oleh pemerintah kota, setelah dirata-ratakan memperoleh nilai 77,13 dengan kriteria cukup. Kendala yang ditemukan oleh siswa dalam pembelajaran daring yaitu siswa ada yang tidak memiliki HP, tidak memiliki kouta yang memadai serta ada pula siswa yang tidak terjangkau oleh jaringan internet. ${ }^{6}$ Selain dampak negative BRD juga memiliki dampak positif diantaranya prestasi siswa semakin meningkat. Hal ini disebabkan karena dalam pembelajaran dari rumah, siswa mendapatkan bantuan secara lebih optimal dari orang tua dan keluarga.

Perencanan karir menjadi salah satu orientasi penyelenggaraan pendidikan nasional. ${ }^{8}$ Siswa yang menempuh pendidikan di satuan tingkat pendidikan seperti sekolah dasar, sekolah menengah pertama, sekolah menengah atas maupun kejuruan tentunya memiliki cita-cita untuk mendapatkan status karir yang ideal. ${ }^{9}$ Menurut Winkle ${ }^{10}$ perencanaan karir merupakan salah satu aspek dari tugas perkembangan karir seorang remaja. Sejalan dengan pendapat Yusuf, menurut Super remaja dengan usia 14-18 tahun, berada pada tahapan kristalisasi untuk tugas-tugas perkembangan vokasional (karir). Tahapan kristalisasi adalah suatu periode proses kognitif. ${ }^{11}$

Karir perlu dipersiapkan sejak kecil, untuk mempersiapkannya bisa dilakukan melalui pendidikan dan pengembangan karir lainnya. Pendidikan tentu saja menjadi aspek penting dalam mempersiapkan karir seseorang. Bahkan melalui pendidikan suatu karir bisa dicapai. Pendidikan secara formal terjadi dari mulai PAUD Sampai perguruan tinggi. Di jenjang pendidikan menengah atas, para siswa berada dalam masa persiapan karir, yaitu suatu masa di mana mereka dihadapkan pada banyak pilihan karir, untuk dipilih mana yang lebih baik berdasarkan pemahaman diri dan pemahaman karir. ${ }^{12}$ Namun pada masa

${ }^{6}$ Mohamad Tohar, "Pelaksanaan Belajar Dari Rumah (Bdr) Pada Sekolah Menengah Atas," Historis: Jurnal Kajian, Penelitian Dan Pengembangan Pendidikan Sejarab 5, no. 2 (2020): 166 70.

${ }^{7}$ Khurriyati, Setiawan, and Mirnawati, "Dampak Pembelajaran Daring Terhadap Hasil Belajar Siswa Mi Muhammadiyah 5 Surabaya."

8 A. Kurniawan, "Urgensi PEran Orang Tua Dalam Membekali Wawasan Karir Pada Anak Selama Pandemi," 2020, 11-18.

9 Alkindi, SD, and Baru, "Pembelajaran Jarak Jauh Penuh Motivasi."

${ }^{10}$ Winkel W. S, Bimbingan Dan Konseling Di Institusi Pendidikan (Yogyakarta: Media Abadi, 2007).

${ }^{11}$ I Dewa Ketut Sukardi, Bimbingan Karir Di Sekolah-Sekolah (Jakarta: Balai Pustaka, 1993).

12 D.K. Adiputra et al., "Development of Vocational Learning Video Based on Local Account in PKN Learning in Elementary School," in Journal of Physics: Conference Series, vol. 1764, 2021, https://doi.org/10.1088/1742-6596/1764/1/012086. 
pandemi Covid-19 pendidikan tidak bisa dilaksanakan sebagaimana biasanya, sehingga proses pendidikan belum bisa optimal dengan menggunakan metode belajar dari rumah (BDR). Berbagai penyesuaian pun dilakukan, termasuk dalam rangka mempersiapkan siswa dalam merencanakan karirnya. ${ }^{13}$

Pengambilan keputusan karir dipengaruhi banyak faktor ${ }^{14}$, seperti Hasil penelitian pada siswa di SMK Bina Sejahtera 1 Bogor, bahwa aspek pengambilan keputusan karir yaitu, (1) aspek sekolah sebesar $71,16 \%$, (2) komunitas $46,03 \%$, (3) sosial ekonomi keluarga 39,42\%, (4) teman sebaya 34,66\% dan (5) keluarga $32,54 \% .{ }^{15}$ Kondisi pembelajaran BDR di masa pandemic, akan melemahkan banyak faktor di atas terlebih faktor sekolah memiliki prosentase tertinggi yaitu sebesar $71,16 \%$. Siswa XI SMK Bina Sejahtera dalam pengambilan keputusan karir didominasi aspek sekolah dengan indikator meliputi pandangan, sikap sekolah mengenai nilai-nilai dalam bekerja dan mengenai tinggi rendahnya status sosial jabatan-jabatan yang dikomunikasikan oleh guru BK/Tenaga pengajar. ${ }^{16}$

Adapun prosesntase hasil penelitian tentang kepuasan layanan bimbingan karir pada siswa kelas XI bawa sebanyak 67\% dari 94 siswa kelas XI merasa bimbingan karir yang diberikan oleh sekolah belum cukup. Sedangkan $33 \%$ lainnya merasa sudah cukup. Selain itu, sebanyak (88,29\% dari 94 siswa kelas XI merasa kekurangan informasi karir. Sedangkan $11,71 \%$ lainnya merasa telah memiliki informasi karir yang cukup. ${ }^{17}$

Dalam kegiatan sekolah tatap muka, layanan karir yang diberikan di sekolah masih belum memuaskan siswa. Hal ini diperburuk dengan system pembelajaran BDR, dimana guru $\mathrm{BK}$ sebagai pusat layanan informasi, bimbingan dan konseling karir tidak memiliki waktu dan jadwal yang tersusun dengan baik untuk memberikan layanan karir siswa.

Pendekatan penelitian yang digunakan untuk mengkaji fenomena ini adalah pendekatan kualitatif dengan metode studi kasus yang didasarkan dengan tujuan yang ingin dicapai yaitu untuk mengetahui dampak belajar dari rumah (BDR) dalam perencanaan karir siswa kelas XI MA NW Samawa. ${ }^{18}$ Sumber dan

13 Titien Agustina et al., "Pandemi Covid-19: Mempercepat UMKM Dalam Sistem Informasi," in Seminar Nasional Sistem Informasi (SENASIF), vol. 4, 2020, 2283-91.

${ }^{14}$ Resi Gusti Nurrega, Hepi Wahyuningsih, and Uly Gusniarti, "Konseling Karir Kelompok Cognitive Information Processing Untuk Meningkatkan Pengambilan Keputusan Karir Siswa," Journal of Psychological Science and Profession 2, no. 1 (2018): 127-34.

${ }^{15}$ Hediyati, "Analisis Eksplorasi Dan Perencanaan Karir Siswa Kelas XI di SMA Negeri Sekecamatan Ciamis" (UNNES, 2019).

${ }^{16}$ Ahmad Mubarik, Endang Setiyowati, and Karsih Karsih, "FAKTORâ€“"Faktor Yang Mempengaruhi Pengambilan Keputusan Karir Siswa SMK Bina Sejahtera 1 Bogor," INSIGHT: Jurnal Bimbingan Konseling 3, no. 1 (2014): 1-6.

17 Nurrega, Wahyuningsih, and Gusniarti, "Konseling Karir Kelompok Cognitive Information Processing Untuk Meningkatkan Pengambilan Keputusan Karir Siswa."

${ }^{18}$ Lexy Moleong, Metologi Penelitian Kualitatif (Bandung: PT Remaja Rosda Karya, 2001). 
jenis data yang dikumpulkan dalam penelitian ini berupa data primer dan data sekunder. Data primer adalah guru BK dan siswa, meliputi hasil wawancara, hasil pengamatan selama proses pembelajaran. Sedangkan data sekunder berasaar dari dokumen-dokumen penting yang ada di sekolah meliputi raport siswa, absensi kehadiran siswa.Adapun objek penelitian terdiri dari dua orang siswa yang teridentifikasi sangat kurang dalam proses belajar BDR, yaitu inisial RS dan SA. Selain itu, ada juga objek pendukung yaitu orang tua dan guru BK. ${ }^{19}$

Teknik pengumpulan data yang digunakan dalam penelitian ini adalah wawancara, observasi, dan dokumentasi. Wawancara dilakukan kepada guru bimbingan konseling dan siswa untuk mengetahui dampak-dampak yang dirasakan siswa selama pelaksanaan belajar dari rumah (BDR).

\section{Hasil dan Pembahasan}

\section{Gambaran Proses Belajar Subjek di Masa BDR}

Proses pembelajaran yang ditemukan di MA NW Samawa dapat diamati dari table berikut ini: 
Tabel 1 Jadwal Pelajaran Siswa Selama 1 (satu) Minggu

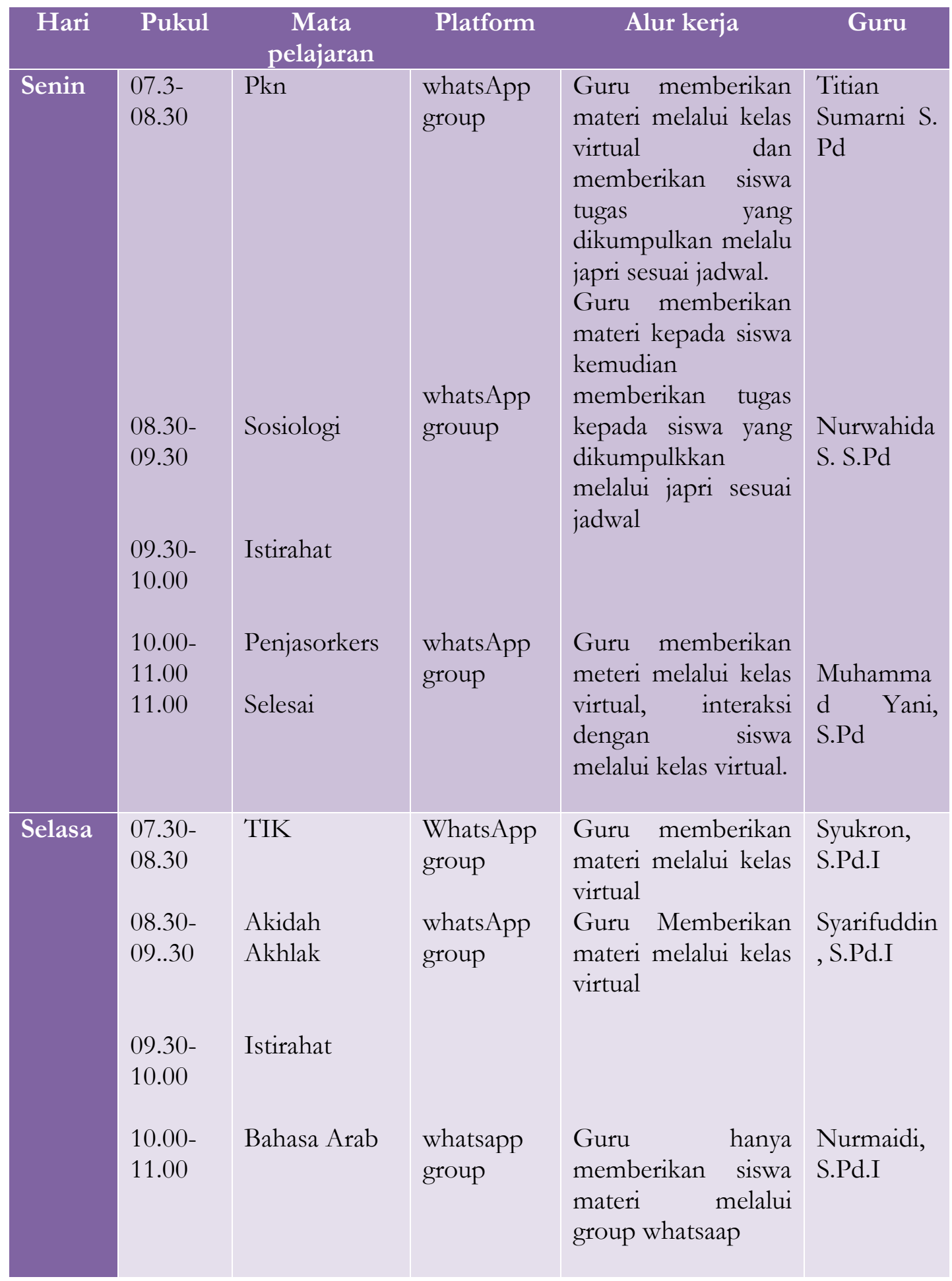




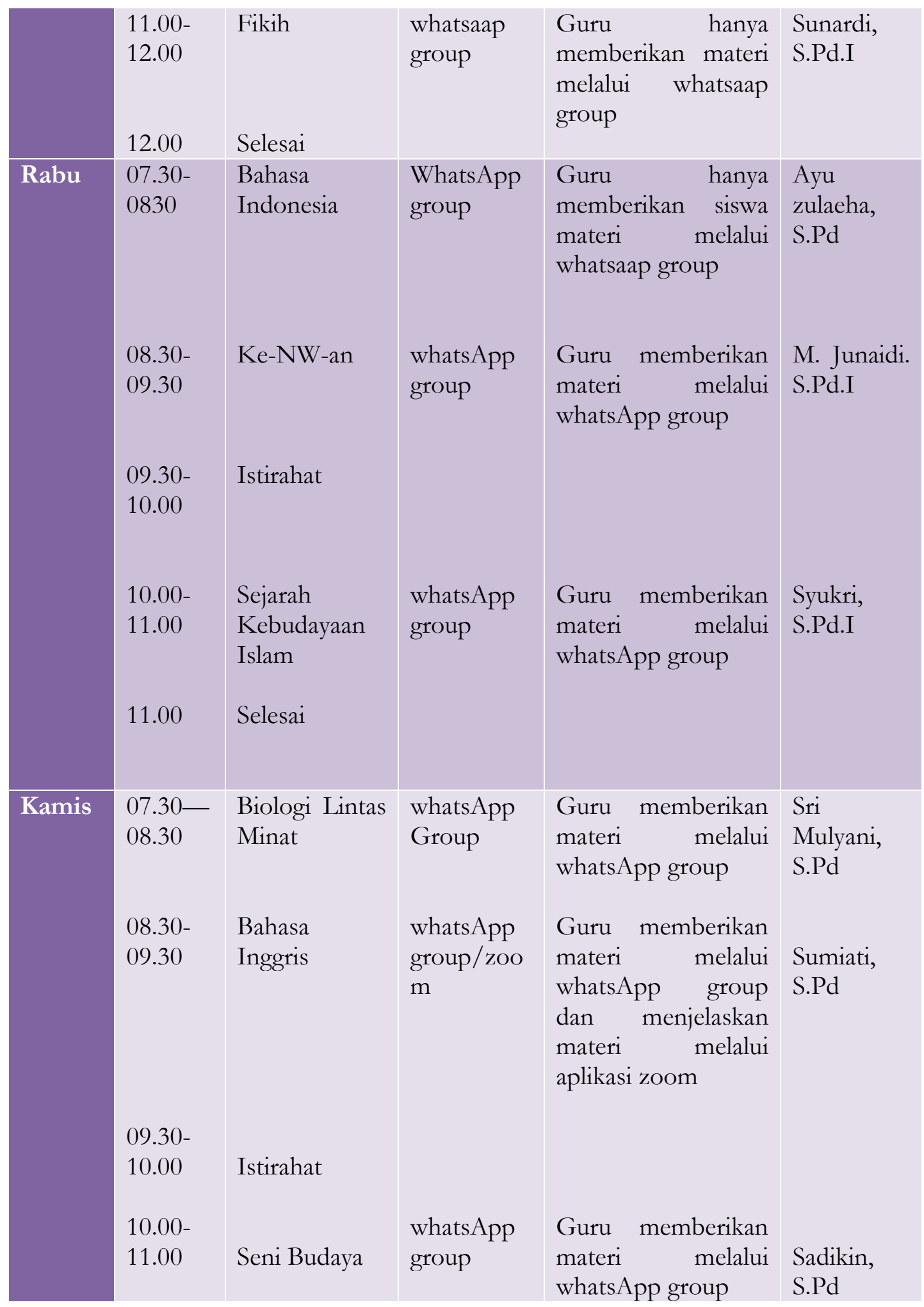




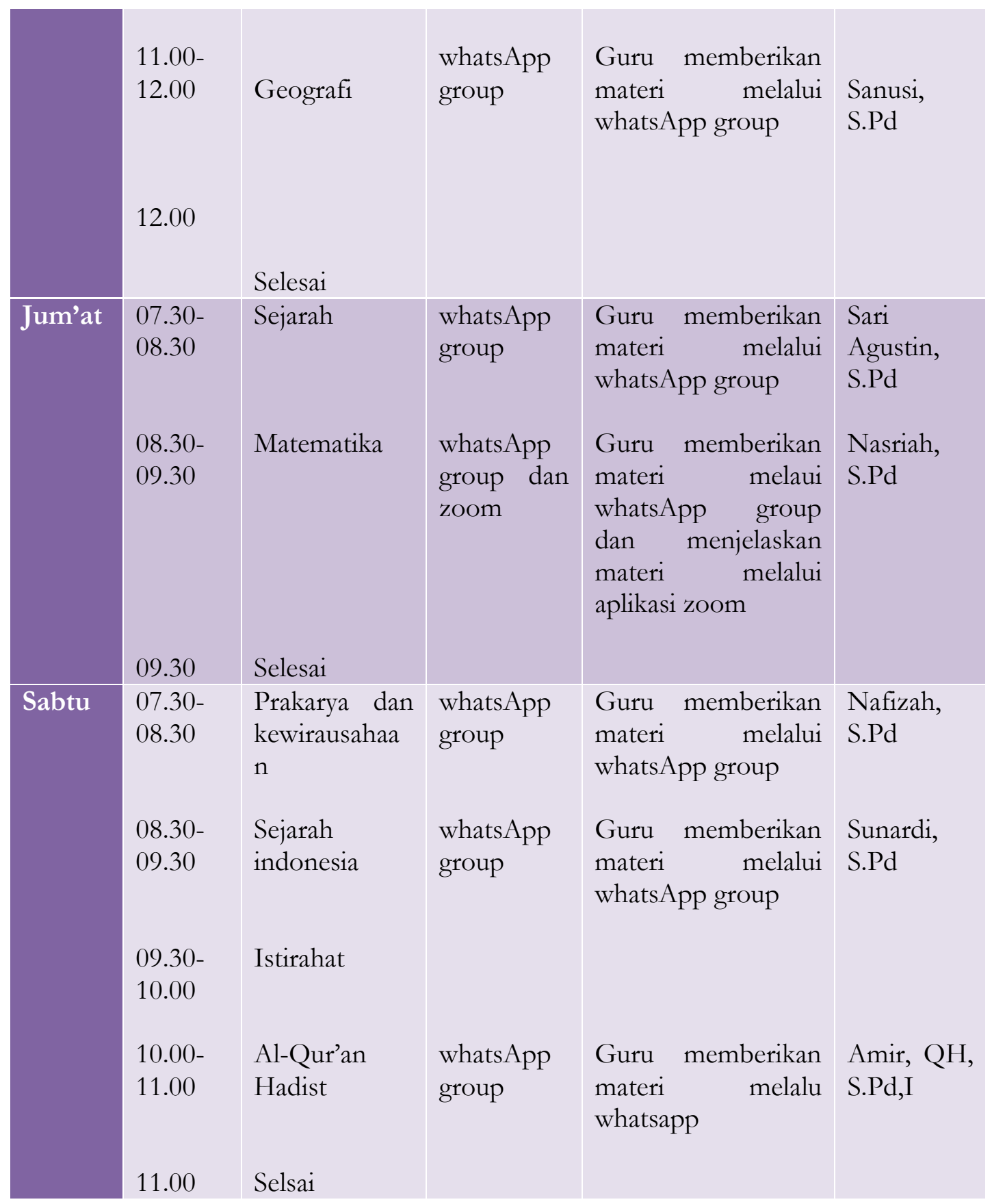

Secara spesifik Guru BK tidak memiliki jadwal untuk memberikan layanan kepada siswa, layanan dapat diberikan dengan cara memanfaatkan jam kosong dari mata pelajaran yang lain. Hal itu menyebabkan guru BK kesulitan dalam memberikan layanan. Selama pelaksanaan belajar dari rumah layanan BK di sekolah MA NW Samawa sangat lemah, guru BK hanya mendapatkan laporan 
dari guru-guru mata pelajaran tentang siswa yang bermasalah selama pelaksanaan belajar dari rumah (BDR). Berdasarkan data yang didapat dari hasil wawancara dengan guru BK di sekolah menyatakan.

"Kalau jadwal untuk guru BK di sekolah ini tidak ada, jadi sulit sekali untuk memberikan layanan kepada siswa selama BDR, kalo di sekolah kan gampang bisa masuk di jam kosong atau waktu istirahat untuk memberikan layanan kepada siswa"

Berdasarkan hasil penelitian observasi dan wawancara di sekolah MA NW Samawa Faktor yang menyebabkan layanan BK lemah adalah yaitu:

1. Kurang terjalinnya kerjasama dan koordinasi diantara guru-guru di sekolah dalam rangka memeberikan pelayanan bimbingan dan konseling kepada siswa,

2. Bimbingan konseling juga sering tidak diperhatikan oleh pihak sekolah karena mayoritas guru lebih fokus pada capaian belajar siswa dan kehadiran siswa selama BDR.

Padahal banyak sekali permasalahan siswa yang menuntut kahadiran guru $\mathrm{BK}$, diantaranya memecahkan masalah belajar, perencanaan penyelesaian karir, dalam hasil wawancara dengan guru BK menyatakan bahwa:

"kalau mau memberikan layanan ke siswa itu susab karena kurang dukungan dari kepala sekolah dan guru-guru, guru BK hanya dibutubkan pada saat ada siswa yang mempunyai kasus yang harus segera ditangani saja makanya saya selama BDR tidak pernah memberikan layanan kepada siswa, saat sekolah tatap muka saja saya harus cari jam kosong baru bisa memberikan layanan kepada siswa".

Analisis kelengkapan sarpras dan interaksi siswa dengan lingkungan sebagai dampak dari kebijakan BDR. Observasi yang dilakukan dari 2 (dua) orang siswa kelas XI MA NW samawa yang berinisial RS dan SA ada beberapa aspek-aspek yang yang diamati oleh peneliti antara lain:

Tabel 2 hasil observasi siswa di MA NW Samawa

\begin{tabular}{|c|c|c|c|c|}
\hline \multirow{2}{*}{ NO } & \multirow{2}{*}{ ASPEK YANG DIAMATI } & \multicolumn{2}{|c|}{$\begin{array}{c}\text { PEMUNCULAN } \\
\text { HASIL } \\
\text { PENGAMATAN }\end{array}$} & \multirow{2}{*}{$\begin{array}{c}\text { NILAI } \\
\text { RATA- } \\
\text { RATA } \\
\text { Per item }\end{array}$} \\
\hline & & BAIK & $\begin{array}{l}\text { TIDAK } \\
\text { BAIK }\end{array}$ & \\
\hline 1 & tata ruang lingkungan sekolah & $\checkmark$ & & 12.5 \\
\hline 2 & Kondisi ruang belajar di rumah & & $\checkmark$ & 0 \\
\hline 3 & Intraksi dengan teman sekelas & $\checkmark$ & & 12.5 \\
\hline 4 & Intraksi dengan guru kelas & $\checkmark$ & & 12.5 \\
\hline 5 & Intraksi dengan orang tua & $\checkmark$ & & 12.5 \\
\hline
\end{tabular}




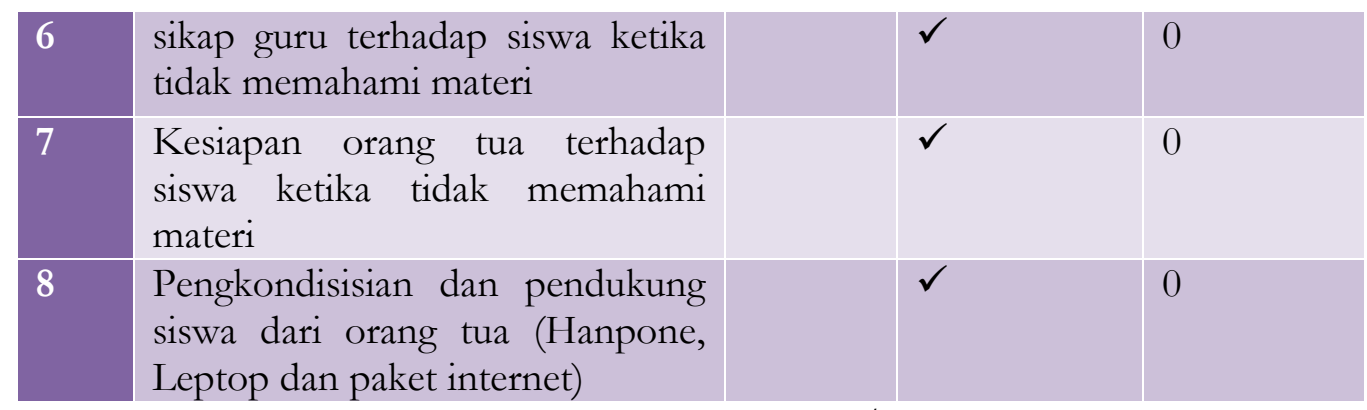

Nilai satuan untuk setiap item $12,5 \%$ didapat dari $1 / 8 \times 100 \%$

Tabel 4.4: Grafik hasil observasi

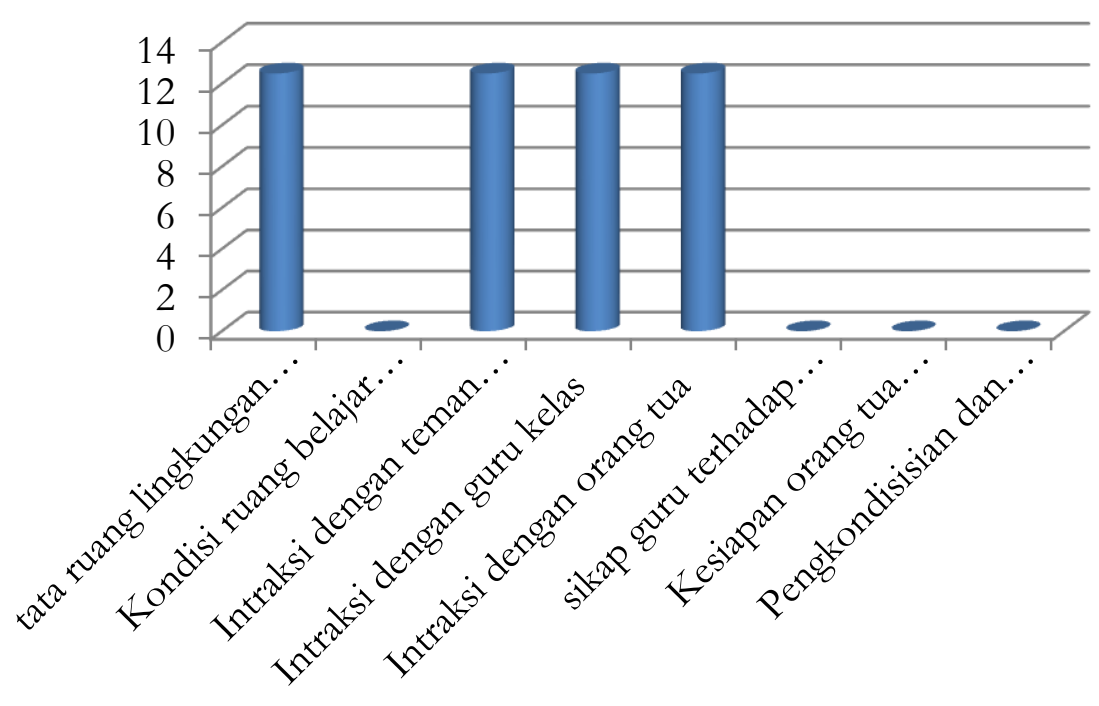

Berdasarkan grafik di atas, dapat diketahui bahwa kedua objek RS dan SA dalam kedelapan aspek-aspek yang sudah diamati menunjukkan bahwa tata ruang lingkungan sekolah yang baik, kondisi ruang belajar di rumah tidak baik, interaksi dengan teman sekelas baik, interaksi dengan guru baik, interaksi dengan orang tua baik, sikap guru terhadap siswa ketika tidak memahami materi tidak baik, pengkondisian dan pendukung terhadap siswa dari orang tua ( $\mathrm{Hp}$, leptop, paket internet) tidak baik. Dari aspek-aspek yang diamati tersebut, dapat menjadi faktor-faktor yang mendukung dan menghambat keberhasilan proses pembelajaran siswa selama pelaksanaan belajar dari rumah (BDR).

Siswa mempunyai beberapa kendala selama BDR sehingga menyebabkan siswa sering tidak menghadiri pembelajaran daring seperti tidak adanya media yang disiapkan orang tua, kesulitan mendapatkan signal, dan dukungan dari orang tua. Seperti pengakuan siswa RS dalam hasil wawwancara menyatakan: 
"saya jarang mengikuti pembelajaran secara daring karena sering tidak ada kuota selain itu saya juga setiap hari menemani ibu berjualan di pasar sampe sore" siswa SA juga menyatakan "di desa itu saya susah signal jadi kalau man ikut belajar online harus naik ke atas pohon untuke cari signal".

Siswa juga sering tidak mengumpulkan tugas yang diberikan guru selama BDR dengan alasan kelelahan setelah bekerja seharian padahal sudah diberikan perpanjangan waktu oleh guru untuk mengerjakan tugas namun tetap saja tugas tidak dikerjakan. Dari hasil wawancara guru BK menyatakan:

"guru-guru sering melapor ke saya babwa siswa sering tidak mengumpulkan tugas, kalo saya tanya alasannya kenapa pasti jawannya kalau karena tidak ada signal dan kuota pasti karena kelelahan karena seharian bekerja banyak alasan pokoknya" dari data hasil wawancara siswa RS juga menyatakan "saya jarang mengumpulkan tugas karena tidak ada waktu untuk mengerjakannya kerena seharian saya bekerja di pasar, malamnya saya nonton tv lalu istirahat" siswa $S A$ juga menyatakan dalam wawancara bahwa "saya seharian ikut membantu ibu saya kerja buruh jagung di ladang jadi saya sering kelalahan jadi malas mengerjakan tugas".

\section{Pemahaman Siswa Tentang Perencanaan Karir}

\section{Analisis Pemahaman Perencanaan Karir Siswa Kelas XI MA NW Samawa}

Berdasarkan hasil penelitian dari dua orang siswa kelas XI IPS selama di Sekolah MA NW Samawa, peneliti menemukan bahwa siswa belum memahami apa itu perencanaan karir. Berdasarkan data yang diperoleh dari hasil wawancara dengan siswa RS menyatakan:

"saya belum memahami apa itu perencanaan karir, karena dari guru ataupun guru BK belum ada yang menjelaskan tentang apa itu informasi karir".

Begitupun dengan siswa SA juga menyatakan dalam hasil wawancara" menurut saya "perencanaan karir itu perencanaan tentang bidang-bidang pekerjaan, saya kurang paham detailnya seperti apa karena belum ada penjelasan tentang itu dari guruguru".

Dari hasil kedua wawancara tersebut dapat disimpulkan bahwa siswa belum memahami apa itu perencanaan karir padahal pemahaman mengenai perencanaan karir sangatlah penting untuk siswa agar siswa lebih fokus dan terarah dalam memikirkan masa depannya akan kemana arah setelah lulus dari sekolah, apakah ingin melanjutkan kejenjang pendidikan yang lebih tinggi atau ingin langsung memasuki dunia kerja sesuai dengan bakat dan minat serta keterampilan yang dimiliki.

Beberapa hal yang menjadi permasalahan siswa adalah kurangnya pemahaman mengenal diri, yaitu mengetahui potensi dan bakat minat yang dimiliki siswa. dalam hasil wawancara siswa SA menyatakan: 
"saya rasa saya tidak memiliki minat terbadap apapun apalagi bakat saya banya suka berjualan seperti ibu saya"

Siswa RS juga menyatakan bahwa "saya suka mengambar tapi sepertinya saya tidak berbakat dalam hal itu karena hasil gambaran saya tidak bagus".

Menurut Dillard (1985: 2-11) langkah-langkah perencanaan karir siswa meliputu: mengenali bakat, memperhatikan minat, memperhatikan nlai-nilai, memperhatikan kepribadian, memperhatikan kesempatan karir dan memperhatikan gaya hidup. Siswa dapat mempersiapkan diri dengan memperhatikan semua langkah-langkah dalam perencanaan karir dan memahaminya dengan baik agar terfokus dan terarah dalam mengambil suatu kepustusan untuk perencanaan karir kedepan setelah lulus sekolah nanti.

Berdasarkan Analisis di atas, diperoleh fakta bahwa faktor-faktor yang menyebabkan lemahnya pemahaman karir siswa RS dan SA adalah:

1. Tidak adanya layanan BK selama BDR

Berdasarkan dari hasil wawancara dengan guru BK di MA NW Samawa yakni berdasarkan kondisi faktual yang dialami oleh guru BK di sekolah mengalami hambatan dalam menjalankan layanan yang telah dirancang. Hal ini dikarenakan tidak adanya alokasi jam bimbingan dan konseling sehingga adanya keterbatasan dalam memberikan layanan bimbingan dan konseling kepada siswa. Hal ini tentu saja beberapa layanan khususnya dalam layanan informasi karir menjadi tidak optimal sehingga siswa sebagai penerima layanan mengalami kekurangan informasi karir yang seharusnya didapat, dengan begitu tentu saja mempengaruhi siswa dalam memahami perencanaan karir secara intensif. Melihat hal tersebut, maka dapat disimpulkan tidak adanya layanan yang diberikan guru BK kepada siswa menyebabkan siswa kurang memiliki bekal wawasan yang luas untuk memulai perencanaan karirnya jadi siswa belum mendapat gambaran mengenai masa depan karirnya. Layanan BK memiliki pengaruh terhadap perencanaan karir siswa karena layanan dari guru BK dapat membantu siswa memantapkan pilihan karir siswa melalui layanan informasi. Dalam hasil wawancara dengan guru BK menyatakan bahwa:

"Selama pelaksanakaan BDR saya selaku guru BK belum pernah memberikan layanan apapun kepada siswa karena banyaknya kendala selama BDR sebinggga siswa belum pernah mendapatkan layanan informasi karir"

Siswa atas nama RS juga menyatakan "saya hanya pernab mendapatkan layanan konseling individu dari guru BK karena saya jarang mengikuti pelajaran daring selama BDR"

Siswa SA juga menyatakan dalam hasil wawanara bahwa "guru BK tidak pernah memberikan layananan apapun kepada saya". 
2. Tidak ada dukungan dan bimbingan dari orang tua terhadap siswa

Alih-alih mendapat dukungan dan bimbingan dari orang tua, siswa lebih sering diminta untuk membantu perekonomian keluarga dengan bekerja. Selama pelaksanaan belajar dari rumah siswa lebih sering membantu orang tua bekerja daripada ikut pembelajaran daring disebabkan karena perekonomian orang tua siswa yang menurun selama pandemi covid-19 sehingga mau tidak mau siswa harus membantu perekonomian orang tua dengan bekerja. Karena siswa setiap hari selalu bekerja dari pagi hingga sore menyebabkan siswa menjadi melupakan pelajaran sekolah, alih-alih belajar dan mengerjakan tugas setelah selesai bekerja siswa malah lebih memilih untuk mengistirahatkan diri sehingga nilai siswa menurun selama BDR. Orang tua dari siswa juga tidak terlalu peduli dengan pendidikan anaknya karena lebih senang melihat siswa bekerja dan mendapatkan uang. Data yang yang didapat dari hasil wawancara dengan orang tua siswa RS menyatakan bahwa:

"untuk apa anak saya sekolah kalau ujung-ujungnya kerja jadi petani juga, kita ini dari keluarga tidak mampu jadi daripada capek sekolah habisin banyak uang untuk beli kuota lebih baik. kerja dapat uang, belajar online juga katanya tidak ada gunanya bukannya jadi pinter malah semakin bodob"

Siswa RS juga menyatakan dalam wawancara bahwa "selama BDR orang tua saya sering sekali menyurub saya ikut bekerja jadi buruh jagung di ladang dari pagi sampai sore sehingga saya sering bolos pelajaran online dan tidak mengerjakan tugas sekolah, orang tua saya lebih senang melihat saya bekerja daripada sekolah"

Dari hasil wawancara dengan siswa SA juga menyatakan "selama BDR saya ikut ibu saya berjualan di pasar biasanya sebelum BDR saya ikut ibu berjualan di pasar setelah pulang sekolah namun selama pelaksanaan BDR saya ikut ibu berjualan di pasar dari pagi sampai sore".

\section{Dampak Belajar dari Rumah Terhadap Perencanaan Karir siswa}

\section{Analisis Dampak BDR dalam Perencanaan Karir siswa kelas XI MA NW Samawa}

Dari hasil analisis yang telah dilakukan peneliti menemukan beberapa dampak BDR dalam perencanaan karir siswa kelas XI MA NW Samawa antara lain yaitu:

1. Siswa kekurangan informasi karir karena pertemuan dengan guru BK terbatas

Hal ini dikarenakan siswa RS dan SA tidak mendapatkan layanan bimbingan dan konseling dari guru BK selama pelaksanaan BDR sehingga siswa mengalami kekurangan informasi karir yang seharusnya didapat. Sehingga mempengaruhi siswa dalam memahami perencanaan karir secara intensif. Berdarkan hasil wawancara dengan guru BK yang menyatakan bahwa: 
"waktu layanan terbatas, guru BK sama sekali belum memberikan layanan bimbingan dan konseling kbususnya yang berkaitan dengan karir masib belum maksimal sehingga menjadi hal yang wajar jika siswa mengalami kebingungan dalam perencanaan dan penentuan arah karir".

2. Lemahnya kebijakan sekolah tentang layanan guru BK yang bermuara pada lemahnya layanan bimbingan karir

Layanan bimbingan dan konseling di MA NW Samawa masih ditemukan lemah. Hal ini dipengaruhi karena tidak ada jam masuk kelas untuk guru BK. Jangankan di masa BDR, masa normal saja guru BK hanya memanfaatkan jam kosong untuk memberikan layanan kepada siswa. Penting sekali kepala sekolah memahami fungsi dan tugas guru BK untuk pendampingan siswa.

3. Kurangnya pemahaman siswa untuk mengenal diri

Kurangnya pemahaman untuk mengenal diri, yaitu mengetahui potensi, kemampuan intelektual, dan mewaspadai kelemahannya. seorang siswa dapat dapat dikatakan memiliki perencanaan karir apabila mereka memiliki pengetahuan dan pemahaman akan diri sendiri, serta mampu menggunakan penalarannya untuk menyesuaikan antara potensi diri sendiri dan dunia kerja. Berdasarkan hasil wawancara dengan siswa RS menyatakan bahwa: "saya tidak memiliki minat terhadap apapun, apalagi bakat khusus"

Siswa SA juga menyatakan dalam wawancara bahwa: "saya suka menggambar tapi sepertinya saya tidak berbakat dalam hal itu karena hasil gambaran saya tidak bagus".

4. Ketidaksiapan siswa dalam perencanaan karirnya

Berdasarkan hasil wawancara dengan siswa RS dan SA, siswa mengalami kebimbangan dan kebingungan dalam merencanakan karirnya, siswa belum mengetahui apa yang akan dilakukan mengenai karirnya setelah selesai menyelesaikan pendidikan jenjang SMA. sehingga siswa menjadi tidak terlalu memusingkan masalah karirnya di masa depan. Berdasarkan hasil wawancara dengan siswa RS menyatakan bahwa:

"saya belum mempersiapkan apapun untuk masa depan saya"

Hasil wawancara dengan siswa SA juga menyatakan bahwa: "saya tidake terlalu memikirkan peribal masa depan saya, saya tidak tabu kedepannya barus bekerja apa".

\section{Penutup}

Layanan bimbingan karir merupakan bidang layanan yang urgen dalam kehidupan siswa. Layanan karir menjadi penting untuk diberikan kepada siswa tingkat sekolah menengah atas, guna mendampingi siswa agar dapat tumbuh sesuai dengan tugas perkemabangannya dengan baik. Hal ini sangat 
membutuhkan dukungan, baik itu dukungan kebijakan maupun dukungan sarana dan prasarana. Terlebih di masa pandemic, dimana pembelajaran di sekolah, menerapkan system belajar dari rumah (BDR). Berdasarkan hasil penelitian diperoleh kesimpulan bahwa kedua objek penelitian siswa RS dan SA belum mampu dalam merencanakan karir masa depannya. Hal ini dipengaruhi oleh minimnya dukungan orang tua untuk pengembangan karir siswa. Lemahnya kebijakan dan system belajar guru BK di sekolah, dikarenakan pendeknya jam belajar siswa di masa BDR ini. Siswa RS dan SA belum memahami langkahlangkah dalam perencanaan karir yang meliputi: mengenali bakat, memperhatikan minat, memperhatikan nilai-nilai, memeperhatikan kepribadian, dan memahami potensi yang dimiliki.

\section{Daftar Pustaka}

Adiputra, D.K., D. Karyaningsih, S.A. Ruiyat, Y. Heryadi, I. Sampurna, and E. Solihatulmillah. "Development of Vocational Learning Video Based on Local Account in PKN Learning in Elementary School." In Journal of Physics: Conference Series, Vol. 1764, 2021. https://doi.org/10.1088/1742-6596/1764/1/012086.

Agustina, Titien, Dodik Jatmika, Asnawi Asnawi, Abdul Wahab, and Devi Rusvitawati. "Pandemi Covid-19: Mempercepat UMKM Dalam Sistem Informasi." In Seminar Nasional Sistem Informasi (SENASIF), 4:228391, 2020.

Alkindi, Usama Luthfi, S Pd SD, and S D N Kalasan Baru. "Pembelajaran Jarak Jauh Penuh Motivasi." Pembelajaran Di Masa Pandemi, Inovasi Tiada Henti (Kumpulan Best Practices Inovasi Pembelajaran), 2021, 43.

Hediyati. "Analisis Eksplorasi Dan Perencanaan Karir Siswa Kelas XI Di SMA Negeri Sekecamatan Ciamis.” UNNES, 2019.

I Dewa Ketut Sukardi. Bimbingan Karir Di Sekolah-Sekolah. Jakarta: Balai Pustaka, 1993.

Jusmawati, Hamzah Upu, and Muhammad Darwis. "Efektivitas Penerapan Model Berbasis Masalah Setting Kooperatif Dengan Pendekatan Saintifik Dalam Pembelajaran Matematika Di Kelas X SMA Negeri 11 Makassar." Daya Matematis: Jurnal Inovasi Pendidikan Matematika 3, no. 1 (2015): 30-40.

Khurriyati, Yulia, Fajar Setiawan, and Lilik Binti Mirnawati. "Dampak Pembelajaran Daring Terhadap Hasil Belajar Siswa Mi Muhammadiyah 5 Surabaya.” Jurnal Ilmiah Pendidikan Dasar 8, no. 1 (2021): 91-104.

Kurniawan, A. "Urgensi PEran Orang Tua Dalam Membekali Wawasan Karir Pada Anak Selama Pandemi," 11-18, 2020. 
Lexy Moleong. Metologi Penelitian Kualitatif. Bandung: PT Remaja Rosda Karya, 2001.

Mubarik, Ahmad, Endang Setiyowati, and Karsih Karsih. "Faktorâ€"Faktor Yang Mempengaruhi Pengambilan Keputusan Karir Siswa SMK Bina SejahterA 1 Bogor." INSIGHT: Jurnal Bimbingan Konseling 3, no. 1 (2014): 1-6.

Nurrega, Resi Gusti, Hepi Wahyuningsih, and Uly Gusniarti. "Konseling Karir Kelompok Cognitive Information Processing Untuk Meningkatkan Pengambilan Keputusan Karir Siswa." Journal of Psychological Science and Profession 2, no. 1 (2018): 127-34.

Palupi, Tri Nathalia. "Tingkat Stres Ibu Dalam Mendampingi Siswa-Siswi Sekolah Dasar Selama Belajar Di Rumah Pada Masa Pandemi Covid19." Jurnal Psikologi Pendidikan Dan Pengembangan SDM 10, no. 1 (2021): 36-48.

S, Winkel W. Bimbingan Dan Konseling Di Institusi Pendidikan. Yogyakarta: Media Abadi, 2007.

Sugiyono. Metode Penelitian Kuantitatif, Kualitatif Dan R \& D. Bandung: Alfabeta, 2016.

Suhandi, Andi, and Issaura Sherly Pamela. "Dampak Musim Libur Covid-19 Belajar Dari Rumah Terhadap Psikologi Anak Sekolah Dasar." Jurnal Gentala Pendidikan Dasar 5, no. 2 (2020): 207-18.

Tohar, Mohamad. "Pelaksanaan Belajar Dari Rumah (Bdr) Pada Sekolah Menengah Atas." Historis: Jurnal Kajian, Penelitian Dan Pengembangan Pendidikan Sejarah 5, no. 2 (2020): 166-70. 
284 | Islamic Counseling: Jurnal Bimbingan dan Konseling Islam, Vol. 5, No. 2, 2021 